\title{
地震発生前の地震活動と地震予知
}

\author{
気象庁 関谷溥
}

(昭和 51 年 7 月 28 日受理)

\section{The Seismicity Preceding Earthquakes and its Significance to Earthquake Prediction}

\author{
Hiroshi SEKIYA \\ Japan Meteorological Agency \\ (Received July 28, 1976)
}

The Izuhanto-oki earthquake of May 9,1974 (M 6.9) was preceded by an anomalous seismicity as shown Fig. 1. The duration from the anomalous seismicity to the mainshock was about 10 years and 4 months. Similar phenomena were also found for 10 events which occurred at shallow depths in Japan.

Considering that these data show a linear relation between the magnitude of earthquakes $M$ and duration $\log T$ (day), the author calculated the coefficient of $\log T=b M+a$ by using the method of least squares as follows:

$$
\log T=b M+a=0.77 \mathrm{M}-1.65
$$

The relation between the above formula and that of TsuboKawa (1969), RIKITAKe (1975) and ScHolz et al. (1973), which indicate with a certain accuracy the magnitude and time of an expected earthquake was given by Fig. 7 .

The author believes that the anomalous seismicity preceding earthquakes is one of the potential parameters which could be employed for earthquake prediction. On the other hand, in some certain fracture zones were found a premonitory change before some events. These phenomena generally are called foreshocks. Anomalous seismicity preceding smaller events cannot clearly be found by data of the Japan Meteorological Agency as shown Fig. 8. It is, however, not certain yet whether such earthquakes were not really preceded by anomalous seismicity.

Our study requires further accumulation of examples from the viewpoint of ascertaining the existence of anomalous seismicity preceding earthquakes by observation network for small earthquakes.

\section{§1. まえがき}

1974 年 5 月 9 日の伊豆半島沖地震（M 6.9）についてはいろいろの研究がおこなわれてい るが，この地震の特徵の 1 つは伊豆半島の先端にそつて, $40 \mathrm{~cm}$ 以上におよぶ右横づれ変異を 示す顕著な地震断層を生じたことであつた.

また，地震活動の面からみると，この断層上には 1964 年 11 月 3 日 20 時 09 分に $M 5.4$ の地震が発生し，この地震は Fig. 1 のように，1963 年 7 月 6 日 01 時 21 分の地震 $(M$ 4.5) 


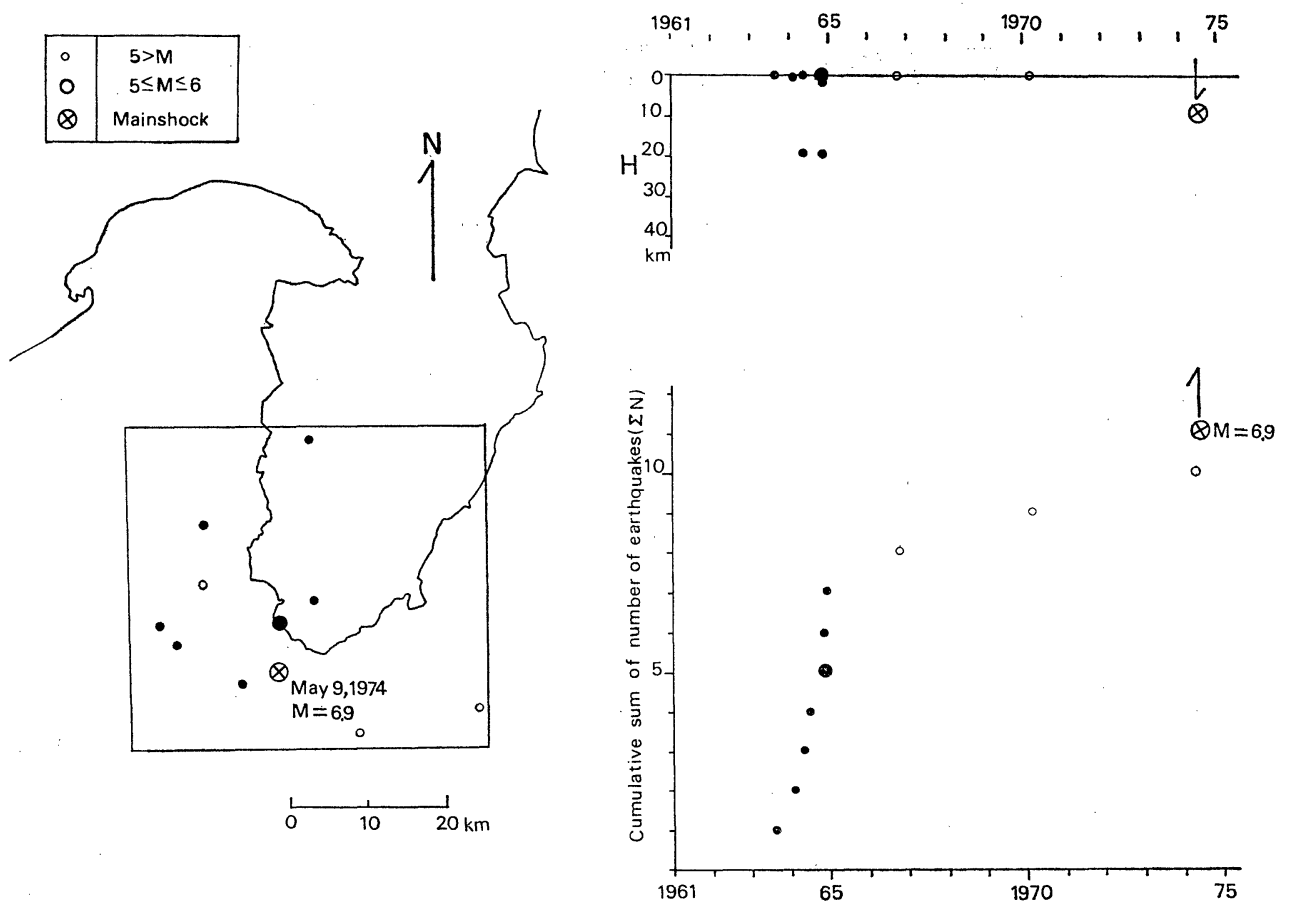

Fig. 1. Seismic activity near focal region observed prior to the Izuhanto-Oki earthquake of May 9, 1974. Solid cercles represent the anomalous seismic activity.

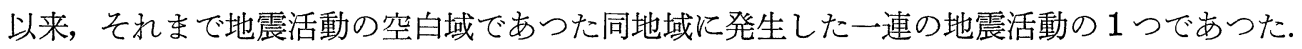

浅発地震の前のある期間中に，震源域を含むある領域内の地殼変動，地震波速度等の変化の あることはすでに報告されており，これらを岩石力学の立場から統一的に説明するものとして は NUR (1972) や SCHOLZ その他 (1973) らの理論がある. そこで, 伊豆半島沖地震の前に 発生したような異常な地震活動が，他の浅発地震の発生前にも起こつているものかどらか。 た，これにともなつて地震波の速度にも変化が現われているかどうかについて，気象庁観測網 で比較的精度よく震源決定されている陸地内に起こつた主な浅発地震について調査を行つた。

\section{§2. 1974 年伊豆半島沖地震発生前の地震活動}

Fig. 1 は 1974 年 5 月 9 日の伊豆半島沖地震 $(M 6.9)$ 発生前の震源域を含む伊豆半島先端部 周辺の 1961 年以後の震央分布, および地震発生の時間的变化を示したものである. 1961 年以 後としたのは, この時代から気象庁の地震計がウィーヘルトから電磁式にかわり, 震源決定法 も図式方法から電計方式に変つたことによる資料の均一性を重要視したためである。しかし， それ以前の同地域の地震活動度は極めて低く, 1926 年より 1960 年までの 35 年間に 4 回の地 

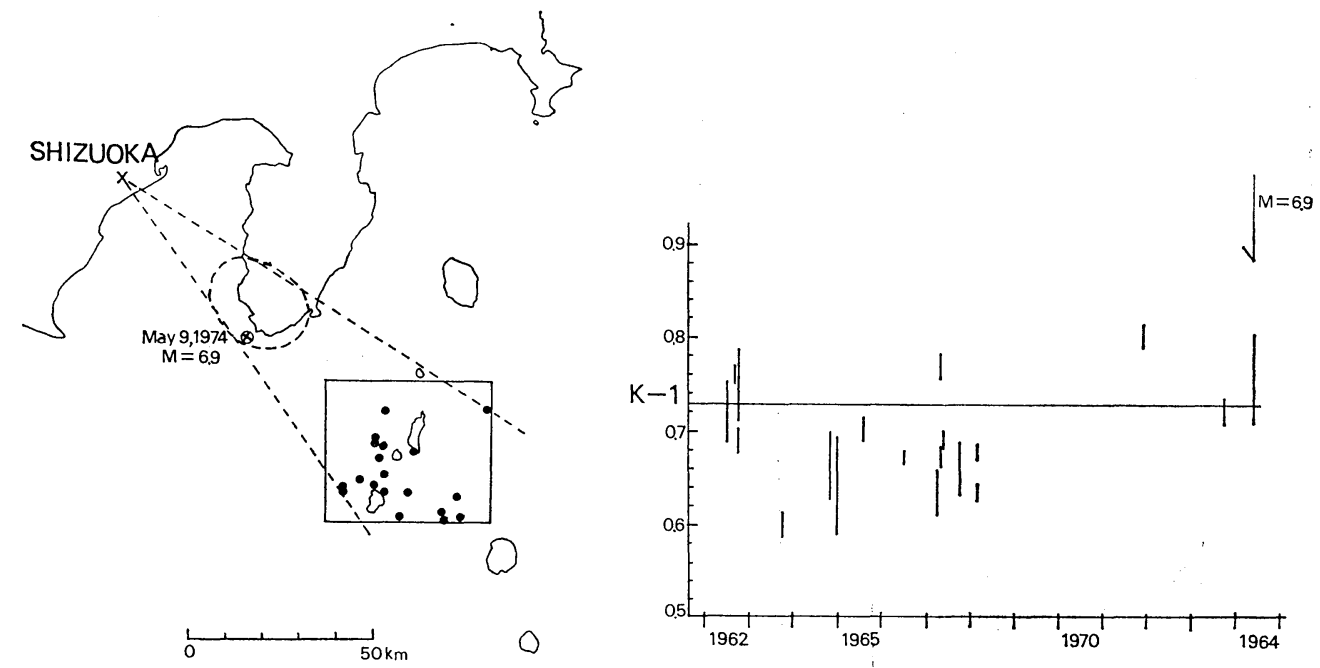

Fig. 2. Change in $V_{p} / V_{s}$ of seismic waves passing the focal region of the Izuhanto-Oki earthquake, 1974.

震が震源決定されているに過ぎない，従つて，1963 年 7 月 6 日の $M 4.5$ の地震から, 1964 年 11 月 3 日 22 時 12 分までの約 1 年 4 か月間に発生した 7 回の地震は，その後の本震発生直 前の 1974 年 3 月 25 日の $M 3.4$ の地震を含めた約 9 年間に 3 回の地震しか震源決定されて いないことからも，この地域としてはやや異常な地震活動とみてよいであろう.なお，この 7 回の地震を他の地震と区別するために黒丸で表示した。 これによると，震央分布からもわかる ように， 7 回の地震は 1974 年伊豆半島沖地震の本震の周辺に分布していて余震域とも大体一 致している，そこで，伊豆諸島の新島周辺に発生する深さ $0-20 \mathrm{~km}$ の浅発地震を使つて，静 岡で明瞭な記象が読みとれるもののみを再調査して, 伊豆半島沖地震の震源域を通つて静岡に 達した地震波の速度比 $V_{p} / V_{s}$ を

$$
V_{p} / V_{s}=K=\frac{S-0}{P-0} \quad \text { すなわち } \quad K-1=\frac{S-P}{P-0}
$$

（但し 0 は震源時を示す）

の式から求めると Fig. 2 となる. 図から 1962 年は平常値に近い值であつたが，異常的な地 震が発生し始めた 1963 年 7 月頃から遅くなり始め, 本震発生の約 3 年前くらいから速くなつ て地震が発生しているのは興味がある.

そして，異常的な地震が発生し始めた 1963 年 7 月 6 日から本震発生までの期間は約 10 年 4 か月であつた. 
関谷 溥
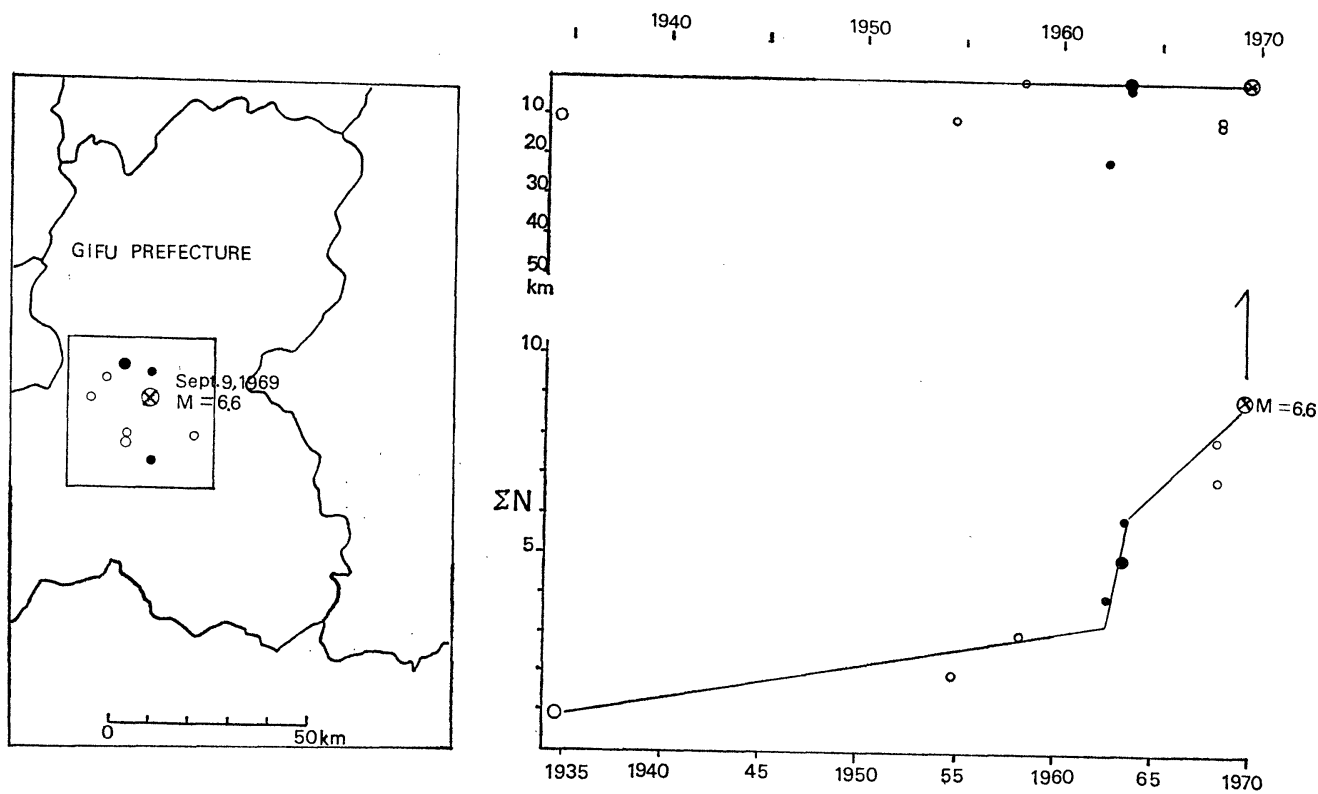

Fig. 3. Seismic activity near focal region observed prior to the central Gifu earthquake of September 9, 1969. Solid circles represent the anomalous seismic activity.

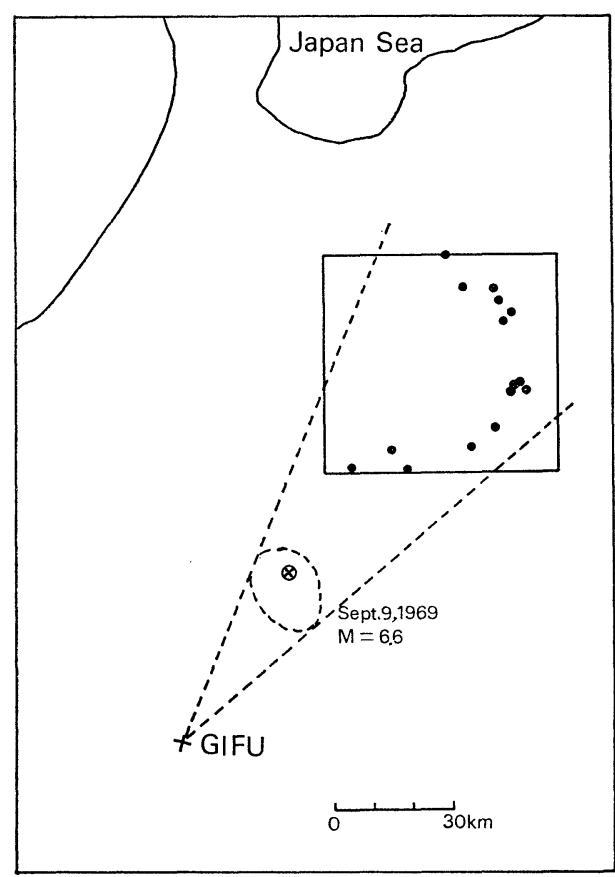

GIFU

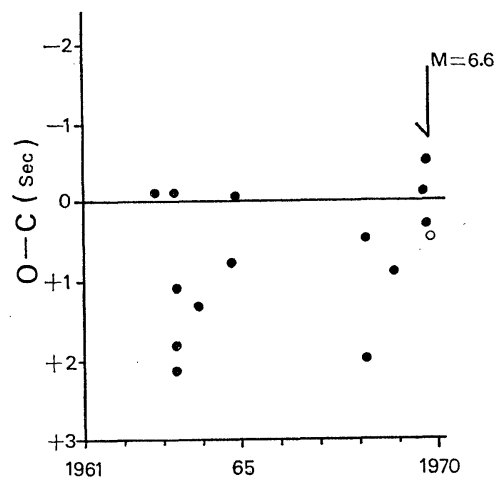

Fig. 4. $O-C$ at Gifu for $\mathrm{P}$ waves passing the focal region of the central Gifu earthquake, 1969. 


\section{$\S 3.1969$ 年岐阜県中部の地震発生前の地震活動}

Fig. 3 は 1969 年 9 月 9 日の岐阜県中部の地震 $(M 6.6)$ の発生前の震源域を含む地域に, 1935 年以後発生した地震の震央分布およびその時間的変化を示したものである.これによる と, 同地域は長い間地震活動度の低い状態が続いていたが， 1962 年 4 月 1 日の $M 4.3$ の地 震から 1963 年 7 月 24 日の地震までの約 1 年 3 か月の間に，3 回の地震がまとまつて図の黒 丸のように発生し, その後約 5 年間平静を保つてから 1968 年 3 月に 2 回発生して, その 1 年 半後に本震が起こつている.

そこで, 長野・岐阜県境に群発する深さ $0 \sim 20 \mathrm{~km}$ の浅発地震を使つて, 岐阜県中部の地震 の震源域を通つて岐阜に達したP波 $O-C$ をプロットすると Fig. 4 となる. 図から地震活動 がやや活発化し始めた 1962 年の後半から $\mathrm{P}$ 波の速度が遅くなつていること, および 1969 年 の地震発生の直前に急に速くなつて本震が発生したことは注目に值する．そして，1962 年 4 月 1 日の地震発生から本震発生までの期間は約 7 年 5 か月であり, 1974年伊豆半島沖地震 $(M$ 6.9) の 10 年 4 か月に比べると約 3 年短かくなつている.

\section{§4. 主な浅発地震発生前の地震活動}

1974 年伊豆半島沖地震と, 1969 年の岐阜県中部の地震の前には, 震源域を含むある領域の 地震活動の異常と, $\mathrm{P}$ 波速度の変化が観測されたので, このような異常現象が日本の内陸に起 つた主な地震についても存在するか否かについて, 地震発生前の地震活動について同様な調査 を行つた.

1974 年 11 月 16 日 08 時 32 分に銚子付近の東経 141 度 15 分, 北緯 35 度 45 分に深 さ $40 \mathrm{~km}, M 6.1$ の地震が発生したが，この時は同地震の余震域である東経 $141^{\circ} 00^{\prime} \sim 141^{\circ} 20^{\prime}$, 北緯 $35^{\circ} 30^{\prime} \sim 35^{\circ} 50^{\prime}$ の域内にこれまでの定常的な地震活動と異なり 1971 年 6 月 3 日 21 時 48 分の地震 $(M 3.9)$ から 7 月 5 日 20 時 40 分までの間に続いて 4 回の地震が発生し, 以後 比較的定常的な活動が続いたあと，本震発生約 4 か月前の 1974 年 7 月から 9 月にかけてやや 活発化して 11 月 16 日に $M 6.1$ の地震が発生した. そしてやや異常的な地震発生から本震 発生までの期間は約 3 年 5 か月であつた.

1965 年 4 月 20 日 08 時 42 分静岡付近に発生した東経 138 度 18 分, 北緯 34 度 53 分,

深さ $20 \mathrm{~km}, M 6.1$ の地震の場合は, 余震域である東経 $138^{\circ} 10^{\prime} \sim 138^{\circ} 30^{\prime}$, 北緯 $34^{\circ} 50^{\prime} \sim$ $35^{\circ} 05^{\prime}$ の域内の地震活動の異常は 1961 年 4 月 23 日から始まり, 翌 1962 年 12 月 13 日 までの間に 8 回の地震が発生している. そして，一旦平静な状態に戻つてから 1965 年 4 月 20 日に本震が発生した. そして, 異常的な地震活動開始から本震発生までの期間は約 4 年で 
あつた。

1962 年 4 月 30 日 11 時 26 分の宮城県北部の東経 141 度 08 分, 北緯 38 度 44 分, 深 さ $0 \mathrm{~km}, M 6.5$ の地震については, 前同様余震域である東経 $141.0^{\circ} \sim 141.4^{\circ}$, 北緯 $38.5^{\circ} \sim$ $38.9^{\circ}$ の域内に 1956 年 5 月 9 日 11 時 52 分の地震 $(M 4.0)$ が起るまでは, 1926 年以後震 源決定された地震がなく，地震活動の空白状態が続いていた。しかし，それ以後 1957 年 1 月 3 日，1958 年 5 月 29 日と地震が起つたあと，1961年 8 月 17 日に深さ $80 \mathrm{~km}, 10$ 月 26 日 に深さ $60 \mathrm{~km}$ と深い地震が起つてから 1962 年 4 月 30 日に $M 6.5$ の本震が発生した. 従 つて，この場合は 1956 年 5 月 9 日の地震から本震発生までの期間は約 5 年 11 か月となる.

1948 年 6 月 28 日の福井地震 $\left(M 7.3\right.$, 深さ $20 \mathrm{~km}$ ) の際は, 東経 $136^{\circ} 15^{\prime} \sim 136^{\circ} 50^{\prime}$, 北 緯 $35^{\circ} 50^{\prime} \sim 36^{\circ} 10^{\prime}$ の域内に 1929 年 4 月 7 日 05 時 34 分の地震（M 4.5） から始まつて, 1933 年 3 月 10 日の地震まで続いて 5 回の地震が起こり，その後同地域には震源決定された 地震のない状態が 15 年余も続いて，1948 年 6 月 28 日に $M 7.3$ の福井地震が発生した. 従つて，この場合は 1929 年 4 月 7 日の地震から本震発生までの期間は約 19 年 3 か月となる.

1968 年 2 月 21 日のえびの地震 $(M 6.1$, 深さ $0 \mathrm{~km})$ の場合は, 同地域には霧島火山観測 所に火山観測用の高倍率地震計 $(5.000$ 倍）が設置してあり，その観測結果によると，地震発 生前の 1965 年 10 月から 1966 年 2 月までの間に，それまでの定常的な活動状態から急に変 化した期間があり,その後 1 年 8 か月の間もとの定常状態に戻り, 本震発生 3 か月前の 1967 年 11 月から また急に地震数が増加し始めて 2 月 21 日に地震が発生している. えびの地震の発 生した地域は加久藤カルデラ内にあつて, 歷史的にも群発地震の多発地带であり, 同時に本震 発生前に前震を伴ないやすい地帯でもある. 従つて, 本震発生前の地震活動に 2 回の異常が観 測されたことは極めて興味がある，すなわち，最初の異常は今汔のべてきたような活動と一致 し, 異常発生から本震発生までの期間は 2 年 4 か月であり, 本震直前の異常は従来一般に考え られている前震活動と考えられる.えびの地震前の高倍率の火山観測用の地震観測から, 従来の 気象庁の一般地震観測で得られなかつた小地震の観測資料が求められたので，同様な微小地震 観測資料のある松代付近の地震に応用して，小規模な地震の前の異常地震活動を調査してみた.

松代地震で最初に震度IVを観測したのは 1965 年 10 月 1 日 17 時 27 分の地震 $(M 4.3$, 深さ $0 \mathrm{~km}$ ) であつたが，地震発生の当初から地震観測所で観測した短周期 10 万倍の地震計 による観測結果によると，最初微小地震が急激に増加した期間があり（8月 11 日～16 日）, その後減少して定常状態となり, 地震発生 3 日前の 9 月 29 日から急に増加を始めて 10 月 1 日に $M 4.3$ の地震が発生した.これは $M 4.3$ といら小規模の地震ではあつたが，1968 年の えびの地震と同様に，地震発生前に地震回数が異常的に変化した期間が 2 回あり，最初の变化 


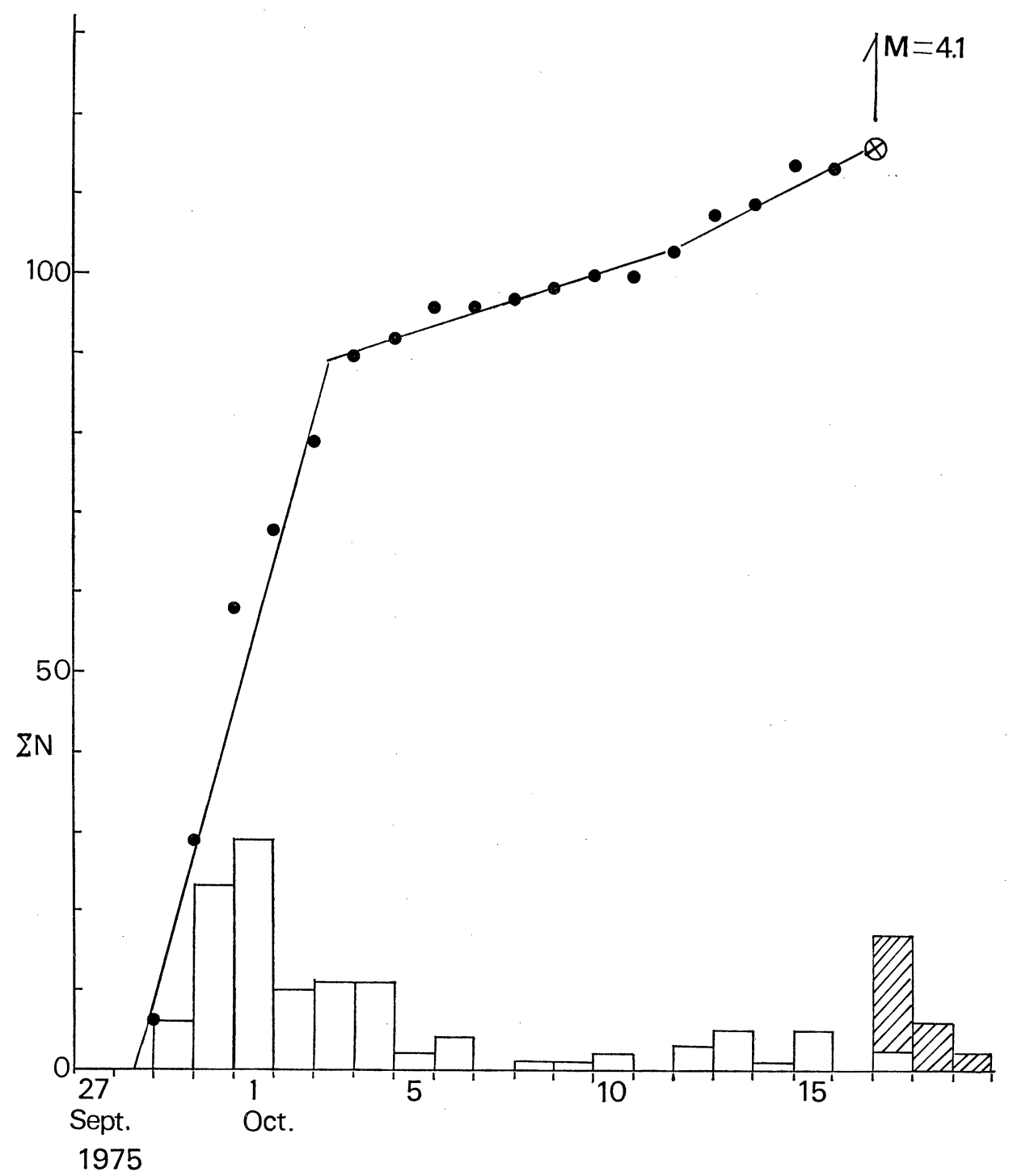

Fig. 5. Variation of daily number of earthquakes near focal region observed prior to the earthquake near Ebino of October 17, 1975.

から M 4.3 の地震発生までの期間は 51 日であり, 2 回目の変化は地震発生の 3 日前から現 われている。

Fig. 5 は，1975 年 9 月 29 日から発生し始めたえびの地域の小地震の場合であるが，図の ように最初急激に地震数が増し，その後一旦沶さまつてから 10 月 17 日 11 時 33 分に $M$ 4.1, 深さ $0 \mathrm{~km}$ の地震が発生した。この場合最初の地震発生からの期間は 18 日であり,さ らに 4 日前から多少の変化が現われている.このように，小規模の地震でもそれにふさわしい 
観測網が整備されていれば，大規模な地震と同様に地震発生前に震源域で異常な地震活動が発 生していることがわかつた．ただ，現在気象庁のこのような微小地震の観測可能な地域は，火 山地域や松代なぞの一部の地域に限られているので，すべての地域に応用できるかどうかは今 後の検討に俟たねばならない。

\section{$\S 5.1923$ 年関東大地震前の地震活動}

さて，それでは 1923 年の関東大地震のような巨大地震についてはどうであろうか. 関東地 震の場合は地震発生の 1923 年 9 月 1 日の時点における観測が，現在のそれと比べて極めて不 十分であり，本震の発生前後の詳しい震源決定は困難である，従つて，今迄のべてきたような 方法はそのままでは適用できない，そこで，地殼变動域（たとえば田島（1970)）などは明ら かになつているので，その変動域の一部であるが，調査の可能な神奈川・山梨・静岡県境を含

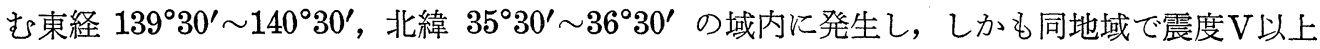
を観測した地震の変動を調べた. この結果同地域では 1782 年 8 月 23 日の小田原地震 $(M$ 7.3）以来平穏な状態を続けていたが， 1841 年 4 月 22 日の地震（ $M$ 6.4）から 1853 年 3 月 11 日の地震（M 6.5） までの間に 3 回震度 $\mathrm{V}$ またはVIが起こつた。 そして，その後一旦平稳 な状態を続けた後， 1887 年 1 月 15 日の地震（ $M$ 6.3） から比較的頻繁に震度 $\mathrm{V}$ 以上の地震 が発生するようになり，1923 年 9 月 1 日に関東大地震（M7.9）が発生している (関谷 1975). 従つて，この場合 1841 年 4 月 22 日の地震から続いて 3 回発生した地震を最初の異常的な活 動と仮定すると，本震発生までの期間は約 82 年となる.

Table 1. List of the earthquakes which ascertained the anomalous seismicity preceding the earthquake.

\begin{tabular}{l|l|r|r|l|l}
\hline \multicolumn{1}{c|}{ Year } & \multicolumn{1}{|c|}{ Earthquake } & $\mathrm{M}$ & $\mathrm{H}(\mathrm{km})$ & Precursor Duration & \multicolumn{1}{c}{ Remarks } \\
\hline Sept. 1, 1923 & Kanto & 7.9 & $10-20$ & 82 years & $\begin{array}{c}\text { 2nd precursor duration, } \\
\text { abot 34 years }\end{array}$ \\
June 28, 1948 & Fukui & 7.3 & 20 & 19 years 3 months & \\
Apr. 30, 1962 & Northern Miyagi & 6.5 & 0 & 5 years 11 months & \\
Apr. 20, 1965 & Shizuoka & 6.1 & 20 & 4 years & \\
Oct. 1, 1965 & Near Matsushiro & 4.3 & 0 & 51 days & 2nd precursor duration, \\
Feb. 21, 1965 & Ebino & 6.1 & 0 & 2 years 4 months & 2nd precursor duration, \\
Sept. 9, 1969 & Central Gifu & 6.6 & 0 & 7 years 5 months & \\
May 9, 1974 & Izuhanto-oki & 6.9 & 10 & 10 years 4 months & \\
Nov. 16, 1974 & near Choshi & 6.1 & 40 & 3 years 5 months & \\
Oct. 17, 1975 & near Ebino & 4.1 & 0 & 18 days & \\
\hline
\end{tabular}




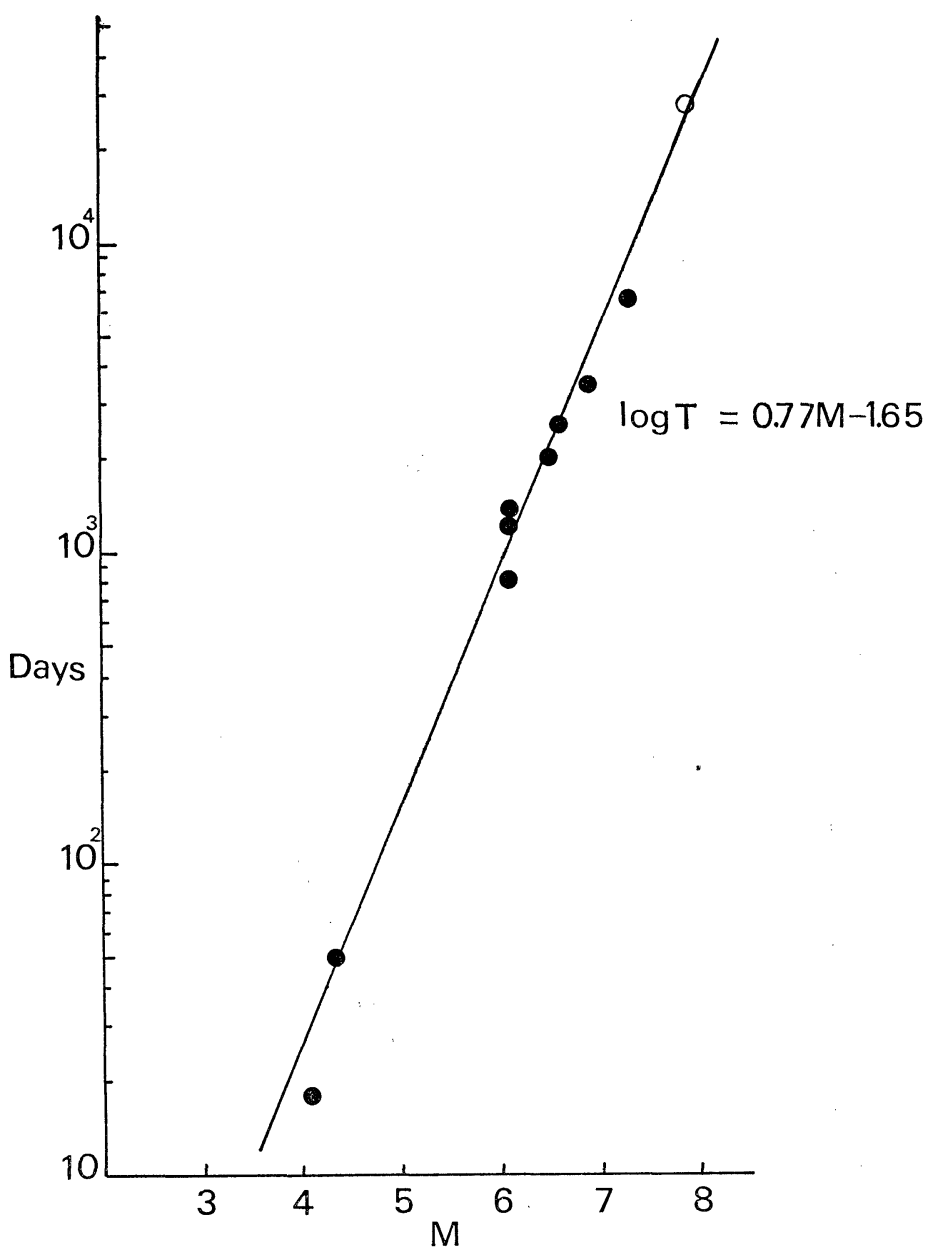

Fig. 6. Logarithmic precursor time in days versus magnitude plots for the data of Table 1.

\section{§6. 異常地震活動開始以後本震発生までの期間と地震の規模との関係}

以上いくつかの浅発地震の震源域を含むある領域内の地震活動の調査によつて, Table 1 の ように地震発生前のある時期に 1 ないし 2 回の異常的な地震活動があり, その後最初発生した 異常地震活動は，地震の規模に関倸のあるある期間を経過した後本震が発生していることがわ かつた．そして異常活動開始から本震発生までの期間（日単位）と $M$ との間には Fig. 6 の 関係が得られるので

$$
\log T=b M+a
$$

として，最小自乗性で保数 $b$ 抢よび $a$ を求めると

$$
\log T=0.77 M-1.65
$$


となるとこで，Fig． 6 とさきに地殼変動の継続期間と地震の規模との間の関係から求めた 坪川の式 (1969)

$$
\log T=0.79 M-1.88
$$

や，地殼の比抵抗， $V_{p} / V_{s}$ の異常, 地下水中のラドンの变化などを総合して求めた SCHOLZ その他 (1973) の式

$$
\log T=0.685 M-1.57
$$

との関係を図示するとFig. 7 となる.これらの図から浅発地震の場合には，まず最初に地壳 の破壞に相当する地震が発生し, その後地盤隆起等の地殼変動や地殼の比抵抗, $V_{p} / V_{s}$ の異常,

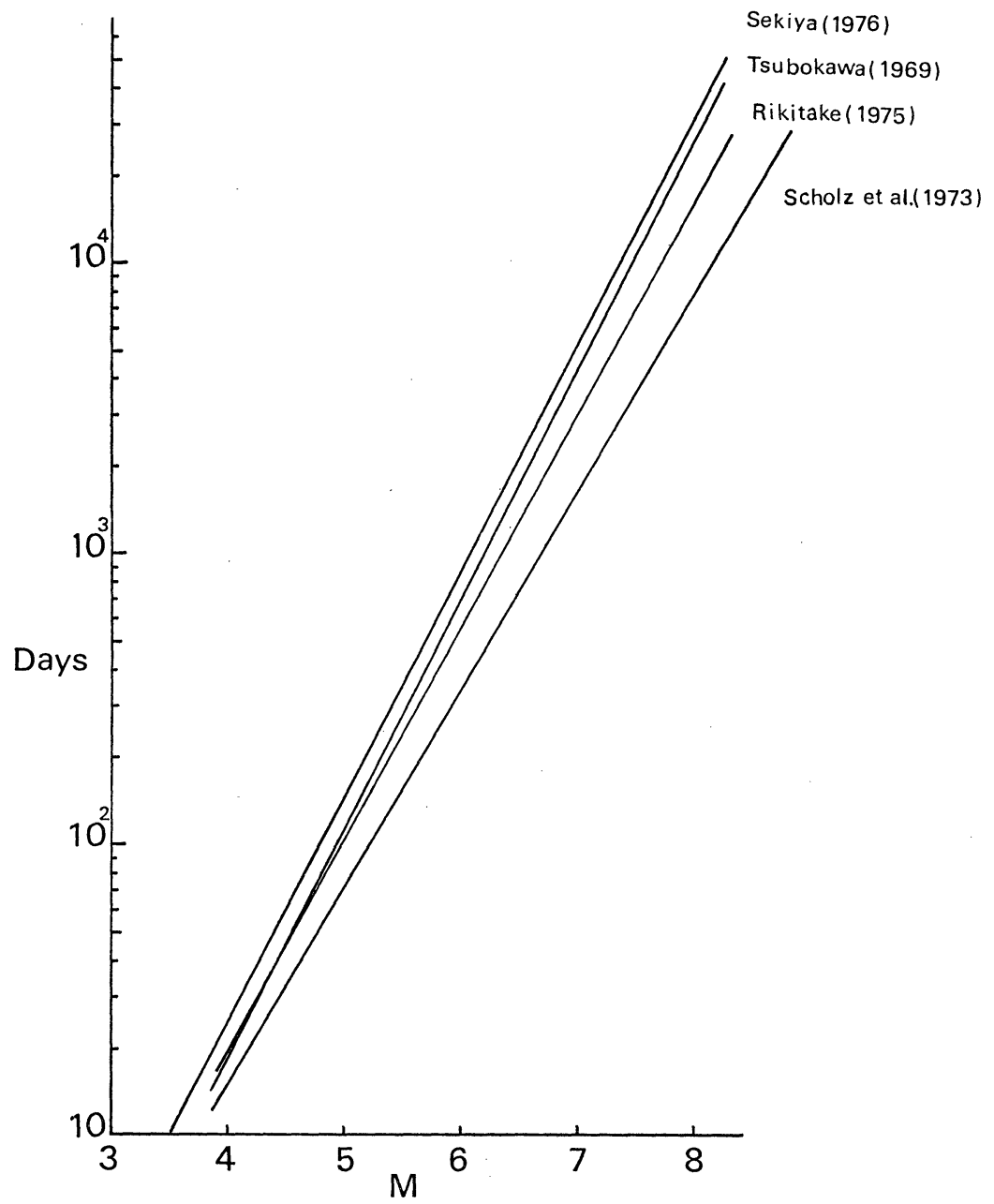

Fig. 7. Relation between the experimental formulae of TsUbokaWA (1969), Rikitake (1975), ScholZ et al. (1973) and SekiYA (1976). 

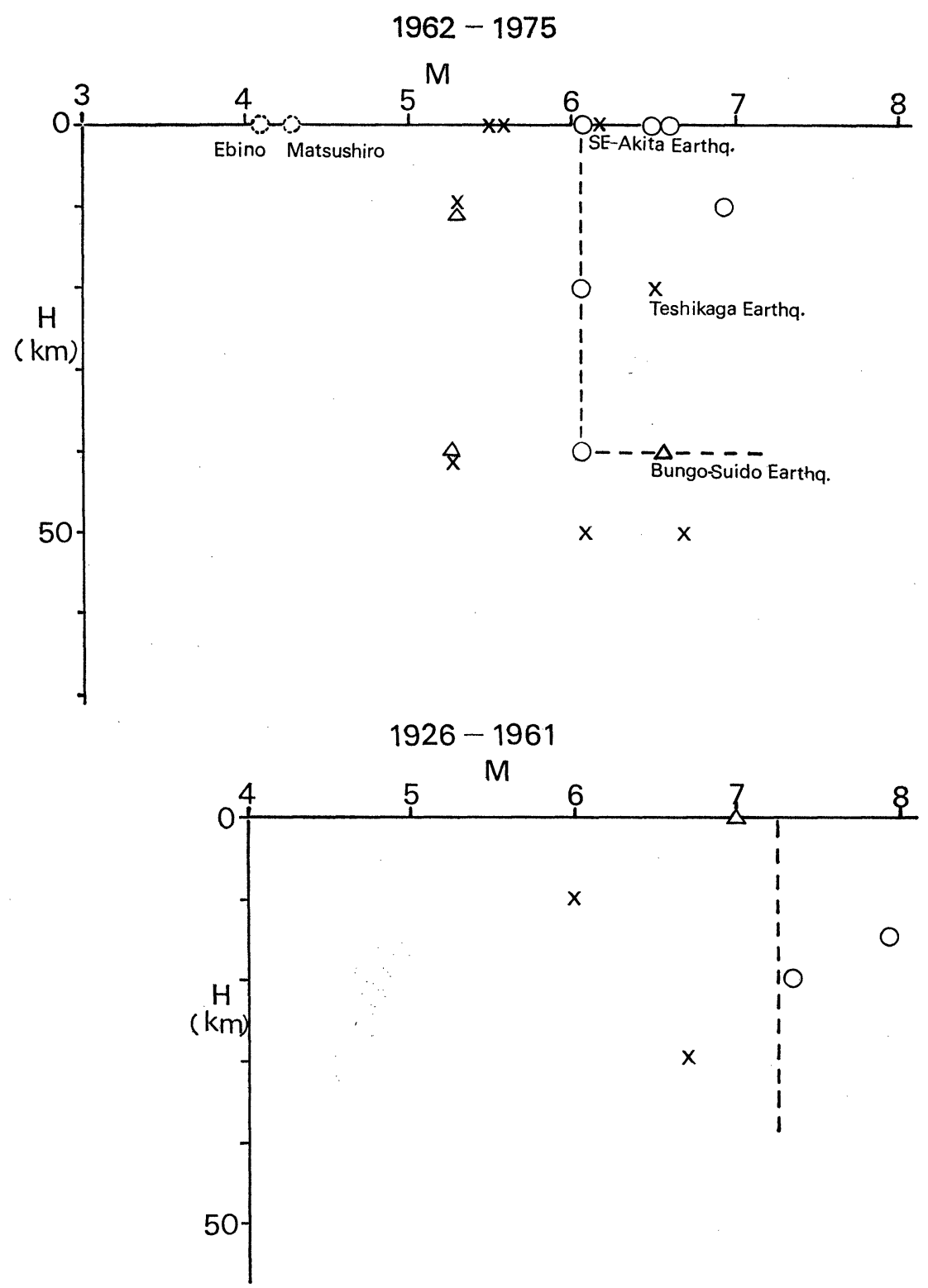

Fig. 8. Relation between the existence of anomalous seismicity preceding earthquake, depth and $M$ of the mainshock.

Open circles represent earthquakes which ascertained the anomalous seismic activity, triangles uncertain and crosses not precursor.

地下水中のラドンの変化などが現われていることになる, また，力武 (1975) は主として日本 とアメリカの地盤傾斜と丕の観測ならびに前震活動とから 
の関係式を求めている.

なお，地震の直前に発生する従来一般に前震と考えられている異常的な地震活動は，起る場 合と起らない場合があり，発生する時期については地震の規模との関係は認められないが，起 る場合は気象庁の観測網でも火山観測など，小ないし微小地震観測の可能な場合，および地帯 構造上の破砕地帯に発生しやすいこともわかつた。

\section{§7. 地震の発生前に異常地震活動が捕捉されない場合}

Table 1 は地震の発生前に震源域を含むある領域に異常的な地震活動が現われた場合だけを とりあげたが，最近日本の陸地で起つた主な地震の場合にも異常的な地震活動がないか，不明 瞭な場合もかなりある.Fig. 8 は 1961 年以前と以後にわけて，地震の規模と深さと異常地震 活動の有無を図示したものであるが，○印は明瞭な場合，、は不明瞭な場合，メがない場合で ある．年代をわけたのは，前述のように震源決定法等がこの時代に变つたため，最近はより小 さい規模の地震まで震源決定されるようになつたためである.これで明らかなことは, 1962 年 以前は $M$ が 7 以上でないと地震活動の異常が確認されたものはないが，1962 年以後は $M 6$ 程度のものでも確認されたものが多い。しかし，震源の深い地震は起つていない。また，1962 年以後の場合, 図の上では異常的な地震活動が現われやすい領域でありながら，1963 年 1 月 28 日の北海道弟子屈付近の地震や，1970 年 10 月 16 日の秋田県南東部の地震は, 地震前に 異常な活動は観測されていない。これは，これらの地域は望月の調査（1975）からも明らかな ように，気象庁観測網では地震観測点などの関係上，小地震が他の地域に比べて捕捉しにくい 地帯でもあるので，それが影響しているためか，あるいはこれらの地域は地震発生の構造上， 本来異常な地震活動を伴ないにくいのか，いづれかであると考えられる．しかし，いづれにし ても Fig. 8 は小または微小地震の観測を強化すれば，より小さい規模の地震でも，地震発生 前の異常地震活動が把握されやすいことを示している.

\section{§8. む す び}

日本の陸地内に起つた浅発地震について地震発生前の地震活動を調査したところ，地震発生 前のある時期に 1 ないし 2 回の異常的な地震活動があり，最初に発生した異常地震活動は地震 の規模に関係のある，ある期間を経過した後本震が発生していることがわかつたとして，異 常活動開始から本震発生までの期間 $T$ (日単位) と $M$ との間には

$$
\log T=0.77 M-1.65
$$

の関係がある.この式は Fig. 7 のように坪川や力武掞よび ScHOLZ その他の式と比べると， 
まず最初に地殼の破壊に相当する地震が発生し, その後地盤隆起等の地殼変動や地殼の比抵抗, $V_{p} / V_{s}$ の異常, 地下水中のラドンの変化が現われるとすると説明しやすい. 従つて, これらの 観測値を併用すれば地震予知のための貴重な資料になりらることがわかつた.

また，このような地震活動の異常を伴なわないものも为なりあるが，小または微小地震の観 測可能な場合は，より小さい規模の地震でも異常現象が観測されているという事実があるので， 観測網による影響が大きいものと思われる．しかし，Fig．８のように少ないながら $M$ の大 きい地震でも異常地震活動を伴なわない例もあるので，今後地震の本質的なものなのか，観測 上のものかを検討する必要があろう.

な拉，地震の発生直前に異常地震活動を伴なら従来一般に前震といわれているものもあるが， 発生する時期については本震の規模との関係は認められない. そして, 地域としては地帯構造 上の破砕地帯に起りやすいこともわかつた. しかし，これもより小さい規模の地震が観測でき るか否かで変つているので, 前同様充分検討すべき問題と思われる.

\section{文献}

望月英志・注か, 1975 , 気象庁の震源検知能力および ISC, USGS 震源との比較, 昭和 50 年地震学 会春季大会講演予稿集, 82 .

Nur, A., 1972, Dilatancy, Pore Fluids, and Premonitory Variation of $t_{s} / t_{p}$ Travel Times, Bull. Seismol. Soc. Am., 62, 1217-1222.

Scholz, C. H., L. R. Sykes and Y.P. AgGarwal, 1973, Earthquake Prediction: A Physical Basis, Science, 181, 803-810.

関谷 溥, 1975, 神奈川・山梨・静岡県境周辺の地震活動, 地震予知連絡会会報, 15, 83-87.

田島 稔, 1970, 最近の関東南部に和ける地殼変動, 地学雑誌, 79, 25-36.

坪川家恒，1969，地殼変動の継続時間と地震の規模との関係について，測地学会誌，15，75-88.

T. Rikitake 1975, Earthquake Precursors, Bull. Seismol. Soc. Am., 65, 1133-1162. 